\title{
Lumen
}

Selected Proceedings from the Canadian Society for Eighteenth-Century Studies

\section{Performances of Sacred Birthday Cantatas by J. F. Fasch (1688-1758) at the Court of Anhalt-Zerbst}

\section{Barbara M. Reul}

Volume 22, 2003

URI : https://id.erudit.org/iderudit/1012257ar

DOI : https://doi.org/10.7202/1012257ar

Aller au sommaire du numéro

Éditeur(s)

Canadian Society for Eighteenth-Century Studies / Société canadienne d'étude du dix-huitième siècle

ISSN

1209-3696 (imprimé)

1927-8284 (numérique)

Découvrir la revue

Citer cet article

Reul, B. M. (2003). Performances of Sacred Birthday Cantatas by J. F. Fasch

(1688-1758) at the Court of Anhalt-Zerbst. Lumen, 22, 27-45.

https://doi.org/10.7202/1012257ar

Copyright (c) Canadian Society for Eighteenth-Century Studies / Sociéte canadienne d'étude du dix-huitième siècle, 2003
Ce document est protégé par la loi sur le droit d'auteur. L'utilisation des services d'Érudit (y compris la reproduction) est assujettie à sa politique d'utilisation que vous pouvez consulter en ligne.

https://apropos.erudit.org/fr/usagers/politique-dutilisation/ 


\section{Performances of Sacred Birthday Cantatas by J. F. Fasch (1688-1758) at the Court of Anhalt-Zerbst}

The Court of Anhalt-Zerbst, a small dukedom about ninety kilometers north of Leipzig and 120 kilometers south of Berlin, supported a 'Princely Orchestra' for over half a century. ${ }^{1}$ Court records surviving at the Landeshauptarchiv of Saxony-Anhalt in Dessau ${ }^{2}$ show that from 1716 until the late 1760s the Court employed a Kapellmeister, with Johann Friedrich Fasch serving the longest -36 years, from 1722 to $1758 .{ }^{3}$ His duties

1 See Hermann Wäschke, 'Die Zerbster Hofkapelle unter Fasch,' Zerbster Jahrbuch 2 (1906): 47-63 for an overview of the changes in orchestral forces at the court of Anhalt-Zerbst after 1721. See also Barbara M. Reul, 'Geburstagsmusiken am AnhaltZerbster Hof während der Amtszeit von Johann Friedrich Fasch (1722 bis 1758), ' J. S. Bach und seine mitteldeutschen Zeitgenossen (Oschersleben: dr. ziethen, 2001) 95-111 and Barbara Reul, 'Johann Friedrich Faschs in Darmstadt überlieferte Geburtstagskantaten für Fürstin Hedwig Friederike von Anhalt-Zerbst,' Johann Friedrich Fasch (1688-1758) und sein Wirken für auswärtige Hofkapellen: Report on the International Scholarly Conference on 20 and 21 April 2001 on the Occasion of the Seventh International Fasch Festival in Zerbst, ed. International Fasch Society (Dessau: Anhalt-Edition Dessau, 2001) 191-210. I am grateful to Mary Térey-Smith, Western Washington University, Bellingham, USA, for her comments on an earlier version of this article. Research support for this article was provided in part by the University of Regina, Canada (Social Sciences and Humanities Research Council of Canada General Research Grant Fund/President's Fund and the Dean of Fine Arts Special Research Fund).

2 Landeshauptarchiv Sachsen-Anhalt, Abteilung Dessau (hereafter: LHSA, Abt. Dessau; previously Landesarchiv Oranienbaum): Konsistorium Zerbst-Rep.15A-IXa, vols. 352-371, hereafter Verzeichniß.

3 From 1715 to 1722 (see LHSA, Abt. Dessau, Zerbster Kammerrechnungen 1715/161721/22) Johann Baptist Kuch had overseen the small orchestral forces at the court. After Fasch's death in 1758 Johann Georg Röllig (1710-1790), who had joined the 
entailed the provision of all music that was required at the Court Chapel and the palace, i.e. the composing, rehearsing and performing of cantatas, masses, passions, overture suites, concertos, sonatas and sinfonias. ${ }^{4}$ Moreover, large-scale sacred cantatas and Serenatas - non-scenic operatic works in one act, often involving allegorical figures - were performed at the Chapel and at the palace, respectively, whenever members of the ducal family celebrated birthdays.

Only two of the approximately one hundred sacred birthday cantatas composed by Fasch for members of the ducal family of Anhalt-Zerbst have survived at the Hessische Landes- und Hochschulbibliothek Darmstadt,

Capelle in 1737, took over the Kapellmeister position. See Hermann Wäschke, 'Die Zerbster Hofkapelle' 47-48 and Hermann Wäschke 'Rölligs Kantate für St. Jakobs-Tag,' Zerbster Jahrbuch 4 (1908) 6ff. For the most up-to-date biographical account of J. F. Fasch's life and works, see Stephan Blaut, 'Fasch, Johann Friedrich,' Die Musik in Geschichte und Gegenwart, ed. Ludwig Finscher, $2^{\text {nd }}$ ed., vol. 6 (Stuttgart: Metzler, 2001), columns 760-775. A brief chronological overview of Fasch's life in English is available at 'Biographies,' International Fasch Society, Zerbst, July 2003 <http://www.fasch.net/english/biographie.htm>.

4 Fasch described his duties during the first few years of his tenure in Johann Friedrich Fasch, 'Lebenslauf des Hochfürstl. Anhalt-Zerbstischen Capellmeisters, Herrn Johann Friedrich Fasch,' Historisch-Kritische Beyträge zur Aufnahme der Musik, ed. Friedrich Wilhelm Marpurg, vol. 3 (Berlin: G.A. Lange, 1757) 124-129. Rpt. in Georg Philipp Telemann und seine zeitgenössischen Kollegen: Dokumentation zu Johann Friedrich Fasch, 1688-1758, Studien zur Aufführungspraxis und Interpretation von Instrumentalmusik des 18. Jahrhunderts 15, ed. Günter Fleischhauer, Walther Siegmund-Schultze and Eitelfriedrich Thom (Michaelstein: Kultur- und Forschungsstätte Michaelstein, 1981) 11-15. See also Barbara M. Reul, 'Musical-Liturgical Activities at the Anhalt-Zerbst Court Chapel from 1722 to 1758: the Konsistorium Zerbst Rep. 15A IXa Primary Source at the Landesarchiv Oranienbaum,' Johann Friedrich Fasch und sein Wirken für Zerbst: Report on the International Scholarly Conference on 18 and 19 April 1997 on the Occasion of the Fifth International Fasch Festival in Zerbst, ed. Konstanze Musketa and Barbara M. Reul (Dessau: Anhaltische Verlagsgesellschaft, 1997) 59-70 and the respective entries in the Concert=Stube inventory from 1743 for a list of cantata cycles composed by Fasch and others authored by fellow-Kapellmeister that were performed at the Court of Anhalt-Zerbst during Fasch's tenure. See Concert=Stube des Zerbster Schlosses, Inventarverzeichnis, aufgestellt im März 1743, ed. Kultur- und Forschungsstätte Michaelstein, with a commentary by E. Thom, facsimile, (Michaelstein/Blankenburg, Harz, 1983), Studien zur Aufführungspraxis und Interpretation der Musik des 18. Jahrhunderts: Dokumentationen, Reprints 4. The performance of cantata cycles performed after 1743 is discussed in Barbara M. Reul, 'Neuerkenntnisse zu Aufführungen von Kantatenzyklen in der Anhalt-Zerbster Schloßkirche nach 1743' Musikkonzepte - Konzepte der Musikwissenschaft: Report on the International [Musicological] Congress of the Gesellschaft für Musikwissenschaft, October 1998 in Halle (Saale), vol. 2, ed. Kathrin Eberl and Wolfgang Ruf (Kassel: Bärenreiter, 2000) 57-64. 
near Frankfurt. ${ }^{5}$ Both works were written and performed on the occasion of Duchess Hedwig Friederike of Anhalt-Zerbst's birthday on 29 October: The Righteous shall delight in 1722 and Praise the Lord O my soul in 1725, respectively. ${ }^{6}$ These special musical birthday works formed part of a day-long celebration at the court. ${ }^{7}$ In the morning the ducal family attended a lengthy worship service at the Court Chapel to honour the individual celebrating a new year of life. ${ }^{8}$ In the afternoon, the congregation gathered at the Chapel for a Betstunde (devotion). The Court Chapel was located in the west wing of the Zerbst palace and had been consecrated in 1718. ${ }^{9}$ It served as the main place of worship for the duke and duchess, their children and relatives, and most likely also their employees. ${ }^{10}$

Large-scale Geburtstagsmusiken form part of a long-standing and respected musical-cultural tradition in Central Germany; J. S. Bach, for

5 In addition to composing birthday cantatas for the reigning duke and duchess, Fasch was required to provide festive sacred music for their relatives if they happened to stay in Zerbst on their birthdays, see Reul, 'Geburtstagsmusiken', 102-106, 108.

6 Hessische Landes- und Hochschulbibliothek Darmstadt, Mus. ms. 292 and 294, respectively. See also the corresponding entries in vols. 352 and 353 of the Verzeichni $\beta$. Note that the entry for Praise the Lord O my soul does not include the title but rather the Bible dictum upon which it is based, Psalm 103, vs. 1-5.

7 Incidentally, ducal birthdays were celebrated whether the individual honoured was present or not. Duchess Hedwig Friederike and her husband, Duke Johann August, were frequently absent on his birthday, 9 August, vacationing at a spa or spending time with her relatives in Jever, a small duchy in lower Saxony.

8 See Barbara M. Reul, 'Johann Friedrich Faschs in Darmstadt überlieferte Geburtstagskantaten für Fürstin Hedwig Friederike von Anhalt-Zerbst,' Johann Friedrich Fasch (1688-1758) und sein Wirken für auswärtige Hofkapellen: Report on the International Scholarly Conference on 20 and 21 April 2001 on the Occasion of the Seventh International Fasch Festival in Zerbst, ed. International Fasch Society (Dessau: Anhalt-Edition Dessau, 2001) 93.

9 The order of the 1718 consecration service is given in vol. 351 of the Verzeichniß. Citizens of Zerbst who lived close to the palace worshipped at St. Bartholomew's Church. Interestingly, both churches shared clergy, with the Court Chapel's Oberhoffprediger regularly preaching at St. Bartholomew's Church. See also Hermann Wäschke, 'Die Schloßkapelle in Zerbst,' Zerbster Jahrbuch 4 (1908): 1-6.

10 For pictures of the palace and the inside of the court chapel see Dirk Herrmann, Schloß Zerbst in Anhalt, Geschichte und Beschreibung einer vernichteten Residenz (Halle: Fliegenkopf, 1998) 132 and 183 as well as his website Schloss Zerbst in Anhalt, Zerbst, Anhalt, July $2003<$ http: / / www.schloss-zerbst.de >. Except for the façade of the East wing, the palace and the city of Zerbst were almost completely destroyed during the Second World War in April 1945. 
example, wrote two cantatas for his noble employer in Köthen. ${ }^{11} \mathrm{~J} . \mathrm{F}$. Fasch's contributions to this genre have received little attention from scholars to date. ${ }^{12}$ In this article, I will outline the context in which performances of birthday cantatas took place at the Zerbst Court Chapel and provide an overview of printed libretti of sacred birthday works for Duchess Hedwig Friederike that survive at the Francisceum Library in Zerbst. Finally, I will examine Fasch's sacred birthday cantata Praise the Lord O my soul.

All festive birthday services held at the Anhalt-Zerbst Court Chapel during J. F. Fasch's tenure involved the orchestra and choir. When he commenced the position of Kapellmeister of Anhalt-Zerbst in September 1722, the Capelle comprised sixteen members, twelve instrumentalists and four choirboys. In his overview of the Zerbst Hofkapelle from 1906, Hermann Wäschke does not identify string players by name but we can safely assume that Fasch must have had at least a quartet at his disposal, possibly the individuals associated with the positions of 'chamber- and court musician' (Rauchfuß), 'court- and town musician' (Grahmann), 'court musician' (Vent) and 'musician' (Sattler?). ${ }^{13}$ Of the five additional 'musicians' mentioned by Wäschke, one sang the soprano solos (Kettner) and one played the Waldhorn (Köth). ${ }^{14}$ There are, unfortunately, no instruments or vocal ranges given for the other 'musicians' but the tutti choral parts were most likely sung by the four choirboys for whose

11 See BWV 1730a 'Durchlauchster Leopold', and BWV 134 'Die Zeit, die Tag und Jahre macht' in Wolfgang Schmieder, Thematisch-systematisches Verzeichnis der musikalischen Werke von Johann Sebastian Bach: Bach-Werke-Verzeichnis (BWV) (Leipzig: Breitkopf \& Härtel, 1990).

12 See Annemarie Clostermann, 'Johann Friedrich Faschs höfische Festmusiken - eine analytische Studie anhand der Kantate Die Gott geheiligte Freude (1722) und der Serenata Freudenbezeugung der vier Tageszeiten (1723),' Johann Friedrich Fasch (1688-1758): Report on the Scholarly Conference in Zerbst on 15 and 16 April 1988 on the Occasion of the $300^{\text {th }}$ Anniversary of his Birth, ed. Kultur- und Forschungsstätte Michaelstein (Michaelstein/Blankenburg, 1989) 50-53, Studien zur Aufführungspraxis und Interpretation der Musik des 18. Jahrhunderts 40, and Eitelfriedrich Thom, 'Einige Bemerkungen zum Vokalschaffen von Johann Friedrich Fasch am Beispiel der Serenata von 1722 Freuden-Bezeugung der Vier Tages-Zeiten,' Johann Friedrich Fasch (1688-1758): Report on the Scholarly Conference Held in Zerbst on 5 December 1983 on the Occasion of the $225^{\text {th }}$ Anniversary of his Death, ed. Eitelfriedrich Thom (Michaelstein: Kultur- und Forschungsstätte Michaelstein, 1984) 45-51.

13 See Wäschke, 'Die Zerbster Hofkapelle' 47-51.

14 See Wäschke, 'Die Zerbster Hofkapelle' 48. Students from the Zerbst Gymnasium Illustre (the local secondary school) possibly provided additional support. 
education Kantor Gattermann was responsible. With regard to brass players, Fasch could choose from no fewer than four trumpeters and a timpanist to add a festive musical touch to his works. An organist (Ulich) joined the orchestra in 1723/24; an oboist (Richter) was hired in 1725/26, and new positions for an alto soloist (Weißflock) and a second oboist (Frödel) were filled in $1727 .{ }^{15}$

Typically, the Capelle performed sacred music on all regular Sundays, feast days such as Christmas or Easter, holidays such as Reformation Day and John The Baptist and on 'Aposteltage' or 'Disciple Days' (Sts. Peter and Paul, St. Matthew, etc.). ${ }^{16}$ Cantatas that involved instrumentalists and vocalists were presented at least three times a week at the chapel: during morning and afternoon services on Sundays, respectively, as well as at Vesper services that were offered at the Chapel on Saturday evenings or on the night before minor holidays. On holidays and feast days the Capelle preceded the cantata with a Lutheran Missa brevis, a figural setting of the Kyrie and Gloria parts of the mass. In addition, the vocalists must have led the congregation in the singing of hymns and responded to liturgical chants sung by the clergy. ${ }^{17}$

Did ducal birthdays form part of the regular church year? ${ }^{18}$ They did not, but when the ducal birthday fell on a Sunday or holiday, a newly composed, festive birthday cantata was performed during the morning service. The regular cantata scheduled for the morning service was moved to the afternoon service, and the cantata intended for that Sunday afternoon was cancelled altogether. Note that the order of a ducal birthday service presents an amalgamation of various liturgical conven-

15 The Capelle grew to 20 permanent members during Fasch's tenure from 1722 to 1758 , cf. the overview of the Zerbst orchestra given in Friedrich Wilhelm Marpurg, 'Die hochfürstliche Anhalt-Zerbstische Capelle,' Historisch-Kritische Beyträge zur Aufnahme der Musik, vol. 3 (Berlin: G.A. Lange, 1757; facs. Hildesheim: Olms, 1970) 130.

16 The Capelle performed cantatas on 'Aposteltage' only when they fell on Sundays or holidays, see Verzeichni $\beta$, vols. $351 \mathrm{ff}$. A specially composed occasional work replaced the regularly scheduled cantata during the afternoon service on that day. See also the entries in the Concert=Stube from 1743 that list a double yearly cycle worth of 'Aposteltage' cantatas composed by J. F. Fasch. Several 'Aposteltage' by Fasch cantatas survive as part of the Zerbster Musikstube collection in LHSA, Abt. Dessau, see items A1-3, A5, A7-9, and A11-15; cf. the respective entries in Rüdiger Pfeiffer, Verzeichnis der Werke von Johann Friedrich Fasch $(F W V)$, ed. Zentrum für Telemann-Pflege und Forschung Magdeburg (Magdeburg: Rat des Bezirkes, 1988).

17 See Wäschke, 'Rölligs Kantate' 8-11. He offers a detailed description of the music performed during worship services at the Court Chapel.

18 Cf. Verzeichniß, vols. 352ff. 
tions, being modelled after services held on minor holidays. ${ }^{19}$ Most likely the Kapellmeister and the Pastor had collaborated on the order of worship, keeping in mind the important social status of the member of the ducal family celebrating a new year of life. Hence, the choir and orchestra first performed a Lutheran Missa brevis followed by a large-scale cantata before the sermon, just as they did for services on minor feast days. After the sermon a festive chorale, no. 176 - 'Lord God, we praise thee' was performed, 'with trumpets and timpani.' (The only other times this particular chorale was heard at the Court Chapel were on Christmas Day, Reformation Day and the Anniversary of the Consecration.) The minister concluded the birthday service with a sung prayer, a Zerbst custom that had been borrowed from the order of service on Christmas Day. Judging from this special liturgical and musical treatment which members of the ducal family received at the Court Chapel on their birthdays, their church 'rank' in the eyes of Anhalt-Zerbst's subjects was similar to that of a minor saint. ${ }^{20}$

Prior to the ducal birthday the Zerbst Hofdrucker printed the cantata texts set to music by the Kapellmeister and made them available to the members of the congregation for use during the service. A total of thirty-four ducal birthday cantata libretti survive at the Francisceum Library in Zerbst. Those pertaining to sacred compositions for Duchess Hedwig Friederike are listed in Overview 1 below. Figure 1 shows the title page of the libretto pertaining to Praise the Lord O my soul. ${ }^{21}$

Overview 1: Libretti for birthday cantatas for Duchess Hedwig Friederike of Anhalt-Zerbst performed at the Court Chapel from 1722 to 1737 (s. Verzeichniß, vols. 352-357, 360 and Francisceum Library Zerbst: A.11.m, A.11.k. $)^{22}$

19 See Wäschke, 'Rölligs Kantate' 9. He noted that the order of birthday services 'in principle adhere to other festive services; however, because of their special occasion they require a very special treatment of the music performed' ('im Grunde wie große Gottesdienste begangen werden, aber ihrer Bestimmung gemäß eine ganz eigenartige Behandlung des musikalischen Teils erfordern'.) All translations in this article are mine.

20 Verzeichniß, see, e.g., vol. 359, entry on 9 August 1736 when Duke Johann August celebrated his 59th birthday.

21 Reprinted with permission of the Francisceum Library, Zerbst. I would like to thank the librarians, Frau Iruta Völlger und Frau Petra Volger, for their assistance. See also Reul, 'Johann Friedrich Faschs ... Geburtstagskantaten' 196.

22 For lists of libretti that were printed on the occasion of ducal birthdays and performed at the chapel during Fasch's tenure (1722-1758) see Reul, 'Geburtstagsmusiken' 


\begin{tabular}{|c|c|c|}
\hline $\begin{array}{l}\text { Church } \\
\text { year }\end{array}$ & $\begin{array}{l}\text { Title of birthday cantata for } \\
\text { Duchess Hedwig Friederike } \\
\text { of Anhalt-Zerbst (Dictum in } \\
\text { Verzeichniß) }\end{array}$ & $\begin{array}{l}\text { Title of libretto (Francisceum } \\
\text { Library, Zerbst) }\end{array}$ \\
\hline 1722 & $\begin{array}{l}\text { 'Die Gerechten müssen sich } \\
\text { freuen' }\end{array}$ & $\begin{array}{l}\text { A.11.m.: 'Die Gott geheiligte } \\
\text { Freude' }\end{array}$ \\
\hline 1723 & 'Mein Hertz ist bereit' & $\begin{array}{l}\text { A.11.m.: 'Gott-gewidmetes } \\
\text { Lob= und Dank=Opffer' }\end{array}$ \\
\hline 1725 & $\begin{array}{l}\text { ['Lobe den Herrn, meine } \\
\text { Seele' - no title listed, only } \\
\text { reference to dictum, Ps. 105, } \\
\text { v.1-3] }\end{array}$ & $\begin{array}{l}\text { A.11.m.: 'Die Zufriedenheit } \\
\text { in Gott' }\end{array}$ \\
\hline 1727 & $\begin{array}{l}\text { 'Ich dancke dir von gantzem } \\
\text { Herzen' }\end{array}$ & $\begin{array}{l}\text { A.11.m.: 'Das } \\
\text { Danck=begierige Hertz über } \\
\text { die Güthe Gottes' }\end{array}$ \\
\hline 1728 & $\begin{array}{l}\text { 'Der Herr ist meine Stärcke } \\
\text { und Schild' }\end{array}$ & $\begin{array}{l}\text { A.11.m.: ‘Das } \\
\text { Christ=Fürstliche } \\
\text { Dank-Opffer vor die erzeigte } \\
\text { Güte Gottes' }\end{array}$ \\
\hline 1730 & $\begin{array}{l}\text { 'Siehe! Der Hüter Israels } \\
\text { schlafet noch schlummert } \\
\text { nicht' }\end{array}$ & $\begin{array}{l}\text { A.11.m.: 'Die schönste } \\
\text { Sicherheit unter dem Schutze } \\
\text { des Höchsten' }\end{array}$ \\
\hline 1731 & 'Ich danke dir darüber' & $\begin{array}{l}\text { A.11.m.: 'Christ=Fürstliche } \\
\text { Andacht' }\end{array}$ \\
\hline 1737 & 'Preiset mit mir den Herrn' & $\begin{array}{l}\text { A.11.k.: 'Die hertzliche } \\
\text { Ermunterung zum Preiße } \\
\text { Gottes' }\end{array}$ \\
\hline
\end{tabular}

102-103 (Duke Johann August) and 104-105 (Dukes Johann Ludwig, Christian August, Prince/Duke Friedrich August, Duchess Johanna Elisabeth); serenata libretti printed for birthdays celebrated by Duke Johann August (not Johann Friedrich as erroneously stated), Duchess Hedwig Friederike, Duchess Magdalena Augusta and the Dowager Duchess Sophie can be found on 106, while serenata libretti for Duchess Johanna Elisabeth and Duke Friedrich August are provided on 108. 


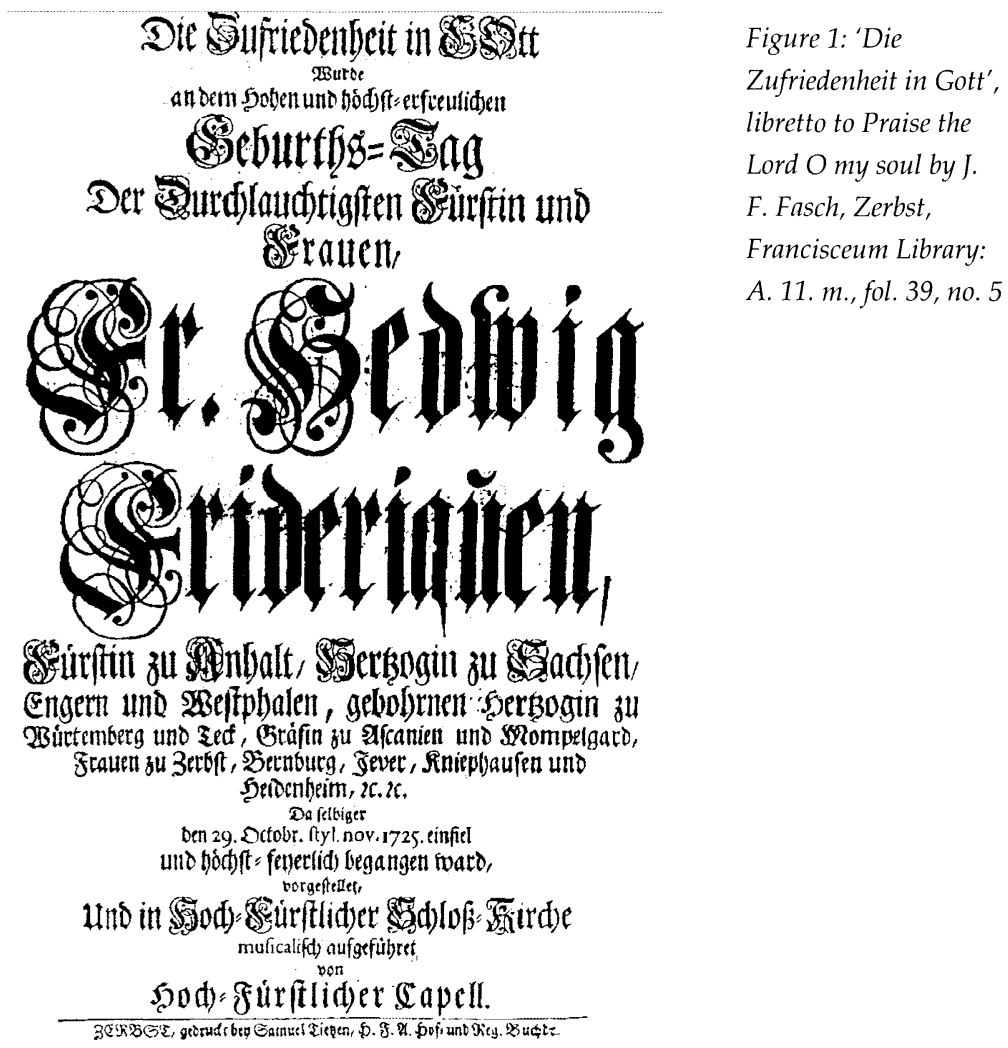

It is interesting to note that Fasch had authored the text for the first birthday cantata that he had ever composed for the court of AnhaltZerbst, The Righteous must delight ('Die Gerechten müssen sich freuen', 1722). It is, therefore, possible that Fasch had also written the libretto for Praise the Lord O my soul in 1725 because Christian Gotthilf Jacobi, a poet and organist from Magdeburg, provided texts for birthday cantatas only from about $1731 .{ }^{23}$ Interestingly, references to the composer(s) of sacred

23 LHSA, Abt. Dessau: Zerbster Kammerrechnungen, 1731/32. Jacobi began supplying texts as early as 1731, not 1734 as had previously been assumed, see Reul, 'Geburtstagsmusiken' 98. See also Bernhard Engelke, Johann Friedrich Fasch: sein Leben und seine Tätigkeit als Vokalkomponist (Halle: C. A. Kaemmerer, 1908) 39. In a letter to Johann Armand von Uffenbach from 1752 Fasch mentioned a 'Jahrgang über die Episteln' ('cycle on the epistles') for which he had provided the texts. He was probably referring to his cantata cycle 'Geistliche Andachten über die Apostolischen Texte' 
cantatas performed on ducal birthdays cannot be found in any of the other surviving libretti. Nor do Zerbst court records contain entries that identify other composers receiving payment for such services. Consequently, J. F. Fasch was most likely responsible for providing all of the ducal birthday cantatas required for the Court of Anhalt-Zerbst during his tenure from 1722 to 1758 .

which was premiered at the Zerbst Court Chapel in $1727 / 28$. Jacobi's successor was the chapel custodian and organist Johann Jacob Ulich to whom Wäschke first drew attention in 1906, see Wäschke, 'Die Zerbster Hofkapelle' 51. New information on Ulich's contribution as a poet for the Anhalt-Zerbst court during Fasch's tenure as Kapellmeister has recently come to my attention. An entry in the Zerbster Kammerrechnungen $(1757 / 58$, p. 273 , entry 47.2596$)$ documents that Ulich had penned the libretto for 'Beglückter Tag,' Fasch's newly-discovered serenata composed for Catherine the Great's birthday in 1757 (see n. 25). Moreover, Ulich's talents as a poet had been called upon for a most significant occasion in the mid-1740s. While carrying out research at the LHSA, Abt. Dessau in the late spring of 2003, I discovered a hitherto-unknown letter by Ulich, dated 20 June 1752 (Kammer Zerbst No. 8457, fol. 41ff.). It proves his authorship of the libretto for Fasch's wedding serenata 'Weichet! Ihr verdickten Schatten!' ('Be gone! You thick shadows'), premiered in Zerbst in celebration of the marriage of Grand Duchess Katharina Alexejewna and Grand Duke Peter Feodorowitsch in St. Petersburg (see Francisceum Library, Zerbst: A. 13.e, fol. $16 \mathrm{ff}$. , and the facsimile edition thereof, Fasch, Serenata). Ulich also noted that he had penned the libretto for a 'Passionshistorie' ('Passion history') according to the Gospel of Luke, which, according to entries in the Verzeichnis was performed at the Court Chapel in 1751. Of the two librettos to Tafelmusiken mentioned in this letter by Ulich, one could be identified as the serenata 'Die reiche Erndte der Freude' ('The bounteous harvest of gladness') at the Francisceum Library Zerbst, A.11.c., fol. 23ff, authored on the occasion of Duke Friedrich August's birthday in 1751. In another letter, dated 23 November 1752 (Kammer Zerbst No. 8457, fol. 35ff) Ulich drew attention to several more librettos for the ducal family. Two are extant at the Francisceum Library Zerbst, the serenata 'Aurora schmückt' ('Aurora adorns', A. 11. c, fol. 25) and the sacred birthday cantata 'Das Opfer der Freude und des Dankes' ('The sacrifice of gladness and gratitude,' A. 11.c, fol. 24). Both were written on the occasion of Duke Friedrich August's birthday in 1752. Furthermore, Ulich confirmed that he had divided a double cantata cycle in 1752 (Erdmann Neumeister's 'Evangelische Kirchenandachten,' originally set to music by Fasch in $1732 / 33$, see Reul, 'Musical-Liturgical Activities' 63-64) to be used as single cycles during Vesper services in 1752/53 and 1753/54, respectively. Incidentally, Ulich's requests for payment (addressed to Duke Friedrich August in June 1752, and to the Kammer-Collegio Zerbst in November 1752, respectively) fell on fertile ground, cf. Zerbster Kammerrechnungen 1752/53. He was paid a total of 30 Reichsthaler (florins) for his services: $10 \mathrm{fl}$. for 'various poetic works for music,' see entry 6.2376 , and $20 \mathrm{fl}$. for 'various poetries to be set to music,' see entry 32.2755 (exact dates are not provided). Moreover, he received $6 \mathrm{fl}$., see entry 13.2839, for 'texts to the funeral music' performed at St. Bartholomew's Church in Zerbst following duchess Hedwig Friederike's death in August 1752. 
After performing at the Court Chapel in the morning, the Capelle moved to the palace to provide special music, including 'Tafelmusiken'. The latter comprised most likely newly conceived concertos, overtures, suites, sonatas, and sinfonias that were performed during a festive luncheon hosted by the duke and duchess. In the evening, numerous of the duke's subjects as well as citizens from other parts of Central Germany offered their congratulations, usually in the form of extended speeches or lengthy pieces of poetry called 'carmina' ${ }^{24} \mathrm{~A}$ lengthy, newly composed non-scenic operatic work, a Serenata, followed. Since there was no opera house or theatre in Zerbst, this type of musical entertainment provided Fasch with the annual opportunity to show off his abilities as a composer of opera. Only two Serenatas composed by Fasch - in 1723 for his new employer, Duke Johann August, and in 1757 for Catherine the Great of Russia, a princess of Anhalt-Zerbst - have survived, a loss which greatly hinders an evaluation of Fasch's musical style in his large-scale secular works. ${ }^{25}$ Finally, a festive fireworks dis-

24 See Barbara M. Reul, 'O vergnügte Stunden, da mein Hertzog funden seinen Lebenstag' ein unbekannter Textdruck zu einer Geburtstagskantate J. S. Bachs für den Fürsten Johann August von Anhalt-Zerbst,' Bach-Jahrbuch (1999): 7-17. In the summer of 1722 when the Kapellmeister position was still vacant, Johann Sebastian Bach had set a 'carmina' to music for Duke Johann August of Anhalt-Zerbst's birthday. As the Kapellmeister of the sister residence Anhalt-Köthen Bach was an obvious choice Bach's brother-in-law was a trumpeter at the Zerbst court (see LHSA, Abt. Dessau, Zerbster Kammerrechnungen 1718/18), and, according to Wäschke, 'Die Zerbster Hofkapelle' 48, Bach's wife Anna Magdalena and her father had performed at the Zerbst palace as far back as 1716. However, entries in the Zerbster Kammerrechnungen only document a visit in 1720/21, see p. 141, entry 1169 (' 6 florins ... for the trumpeter Wilcke from Weißenfels ...', '6 Reichsthaler ... dem Trompeter Wilcke aus Weißenfels ...') and entry 1170 ('12 florins ... for his daughter [Anna Magdalena] because she had sung with the orchestra several times ...', '12 Reichsthaler ... deßen Tochter so in der Capelle einige Mahle mitgesungen ...').

25 See Clostermann's discussion of the 1723 work, 50-53. Fasch's serenata from 1757, 'Beglückter Tag', written in honour of the birthday of Catherine the Great of Russia (1729-1796), formerly princess Sophie Auguste Friederike of Anhalt-Zerbst, is only one among many serenatas performed at the court chapel after her departure for Russia in 1745; see the respective entries in the Verzeichni (always on the Sunday following her birthday on 2 May), as well as references to the authors of birthday cantata librettos - most importantly C. G. Jacobi and J. J. Ulich - in the respective volumes of the Zerbster Kammerrechnungen at LHSA, Abt. Dessau. The 1757 serenata, composed the year before Fasch's death, forms part of the extensive holdings of the Berlin Singakademie that were recently returned from Kiev, Ukraine, to the German State Library in Berlin. See the written version of a paper presented by Elena Sawtschenko on the occasion of the Eighth International Fasch Festival, Zerbst, 
play brought to a close the elaborate birthday celebrations at the AnhaltZerbst palace.

Only two Zerbst birthday cantatas by Fasch - Mus. ms. 292, Die Gerechten müssen sich freuen (The Righteous must rejoice) and Mus. ms. 294, Lobe den Herren (Praise the Lord) - have survived at the Hessische Landesund Hochschulbibliothek Darmstadt, south of Frankfurt am Main. ${ }^{26}$ In contrast, no fewer than 75 instrumental compositions found their way from Zerbst to Darmstadt via an exchange of sheet music between Fasch and Christoph Graupner, a personal friend and teacher of Fasch and Kapellmeister of the Hessian Residence. ${ }^{27}$ It is safe to assume that Graupner performed Fasch's instrumental compositions because he prepared instrumental parts for his Darmstadt court orchestra. ${ }^{28}$ No such parts survive for these birthday compositions, most likely because reworking choral compositions that had been tailored to the performance requirements of another Court Chapel would have been too time-consuming for Graupner. ${ }^{29}$

Why would Fasch have sent these birthday cantatas to Graupner, fully aware that they would not be performed? A lack of supporting evidence prohibits a conclusive answer at this time, but several possible

Germany, 5 April 2003, entitled 'Zwei bisher unbekannte Werke von Johann Friedrich Fasch in den aus Kiew zurückgegebenen Beständen der Sing-Akademie zu Berlin'. It will be included in vol. 9 of Fasch-Studien, Johann Friedrich Fasch und der italienische Stil, ed. Internationale Fasch-Gesellschaft, forthcoming.

26 The Hessische Landes- und Hochschulbibliothek Darmstadt Library holds the second-largest collection of instrumental works by the Anhalt-Zerbst Kapellmeister, cf. Pfeiffer, FWV. For a numerical overview, see Ursula Kramer, 'Faschs Beziehungen zu Darmstadt - Die Bestände der Hessischen Landesbibliothek', Johann Friedrich Fasch (1688-1758) und sein Wirken für auswärtige Hofkapellen: Report on the International Scholarly Conference on 20 and 21 April 2001 on the occasion of the Seventh International Fasch Festival in Zerbst, ed. Internationale Fasch Society (Dessau: Anhalt-Edition Dessau, 2001) 147.

27 See Fasch 126-127. Fasch recalled in his autobiographical article published in 1757 that he had spent 14 weeks in Darmstadt, studying with his former Thomasschule prefect Graupner as well as the Hessian court orchestra's concertmaster Grünewald. Both must have liked Fasch very much since they not only 'received him with love' ('mit vieler Liebe aufgenommen') but also provided composition lessons free of charge. See also Kramer 146-160.

Cf. Pfeiffer, $F W V$.

29 For the most recent, though partial, bibliography of Graupner's music see Christoph Graupner 1683-1760, ed. Christoph Grosspietsch, May 2000, Technische Universität Darmstadt, July 2003 <http://elib.tu-darmstadt.de/lhb/graupsite/Graupner06.html>. 
scenarios come to mind. Fasch could have presented personal copies of these birthday cantatas as tokens of devotion to his former teacher, in an attempt to show Graupner how much he had improved as a composer since his student days in 1713. On the other hand, the Darmstadt Library might not necessarily have received these two occasional works during Fasch's lifetime but could have acquired them in the late nineteenth or early twentieth century to complete its large collection of music by Fasch. $^{30}$

In view of their structural design and their length The Righteous must delight and Praise the Lord were both modelled after Fasch's cantatas for minor feast days (see Overview 2). They involve an orchestra as well as vocal soloists and a choir who perform through-composed choral movements, recitatives, arias, duets and chorales. Praise the Lord was conceived as a double cantata, i.e., a choral work in two parts comprising four movements each. On regular Sundays or holidays double cantatas were divided between the morning and afternoon services. On ducal birthdays, however, only one lengthy morning service was held at the court chapel, and all eight movements of a double cantata were performed before the sermon. ${ }^{31}$

Fasch had based the structural design of Praise the Lord on his own musical setting of the double cantata cycle The string-playing of the heart on the day of the Lord (Das Saiten=Spiel des Hertzens am Tage des Herrn). This collection of cantatas was performed at the Zerbst Court Chapel during the church year of 1724/1725. Overview 2 shows the design of Praise the Lord, including a lengthy opening movement, unaccompanied and accompanied recitatives, two duets and two chorales.

Overview 2: J. F. Fasch, Cantata Praise the Lord, FWV D: L2, Hessische Landes- und Hochschulbibliothek Darmstadt, Mus. ms. 294, structure (DAcc.-Duet-Ch-Rec.-Trio-Rec.-Ch)

30 See Reul, 'Johann Friedrich Faschs ... Geburtstagskantaten' 195-199 and Kramer 146-151.

31 With regard to performance practice at the Zerbst Court Chapel during and after Fasch's tenure in Zerbst (1722-1763), see Reul, 1997 and Reul, 2000. Fasch regularly repeated his own cycles of cantatas as well as cycles composed by his colleagues Georg Philipp Telemann, Friedrich Wilhelm Zachow and Gottfried Heinrich Stölzel. Fasch also divided so-called 'double cycles' (comprising two cantatas for each Sunday and holiday) into two 'single' cycles and performed them during Vesper services on Saturdays in consecutive church years. 
[Part 1:]

1. Tutti 'Lobe den Herrn, meine Seele' and closing fugue 'Der deinen Mund frölich machet', 3/8, D Major, $308 \mathrm{~mm}$., soprano, alto, tenor, bass (SATB), 3 trumpets, timpani, 2 oboes, strings and Basso continuo (B. c.).

2. Accompanied recitative (Accompagnato), 'Durchlauchtigste! Dein Gott=ergebner Sinn', 4/4, 29 mm., tenor, strings and B. c.

3. Duet, 'Dein Seufzen ist Gott nicht verborgen', 4/4 (54 mm.) and 3/4 (58 mm.), $113 \mathrm{~mm} ., \mathrm{b}$ minor, tenor, bass, oboe, strings and B. c.

4. Chorale, 'Gieb dich zu frieden', 2/2, D Major, 26 mm., SATB, 2 oboes, strings and B. c. 'Con i stromenti'

[Part 2:]

5. Secco recitative (unaccompanied), 'Dann kan[n] man auch zu frieden seyn', 4/4, b minor, $23 \mathrm{~mm}$., bass and B. c.

6. Duet da capo, 'So breite dann die Glaubens=Hände', 4/4, D Major, $33 \mathrm{~mm}$., soprano, alto, oboe, 'Vox humana' (obbligato organ part) and B. c.

7. Secco recitative/Tutti/Accompagnato: secco recitative 'Beglücktes Anhalt!', 4/4, D Major, 8 mm., tenor and B. c.; Tutti ('Tuttiaccompagnement') 'Die Freude unsers Theuresten August', 6 mm., SATB, 2 oboes, strings and B. c.; Accompagnato 'Ihr sey von nichts, als lauter Wohl bewust', $9 \mathrm{~mm}$. bass, tenor, strings and B. c.

8. Chorale, 'Gott, nimm das Opffer an', 'Con i strom[enti]', 2/2, chorale setting not entered in score; references to number in Zerbst hymnal from 1730 and Zerbst Kantional (accompaniment edition) from 1738 missing.

As part of the festive opening movement of Praise the Lord Fasch composed a charming fugue, 'Der deinen Mund fröhlich machet' (literally: 'He who delights your mouth'). In 1728 Fasch adapted this fugue as the 'Cum sancto spiritu' passage in the Gloria movement of his Missa brevis in D Major (FWV G: D3). ${ }^{32}$ Since Fasch's weekly workload at Zerbst

32 I would like to thank Brian Clark for drawing my attention to the above. See Reul, 
kept increasing steadily, he had obviously taken the opportunity to rework this fugue several years after its premiere (and probably only performance) in 1725. Instead of trying to find a German text that fit the music Fasch preferred the Latin Gloria text, cleverly moving the metric accent and beginning on the down-, not the upbeat. He also changed the melodic contour and placed the highest note, $\mathrm{a}^{2}$, on the word 'Dei' (see musical examples 1 and 2).

Example 1: J. F. Fasch, Praise my soul, FWV D: L2, movement 1, closing fugue 'Der deinen Mund fröhlich machet', soprano, mm. 170-178

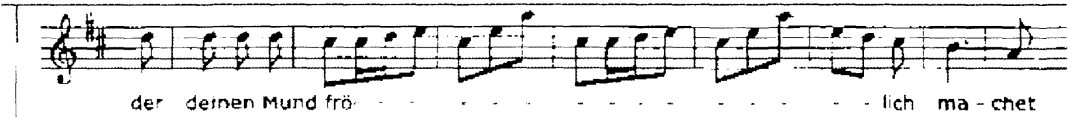

Example 2: J. F. Fasch, Missa brevis D Major, FWV G: D3, Gloria, closing fugue, 'Cum Sancto Spiritu in gloria Dei, Amen, Amen', soprano, mm. 288-294

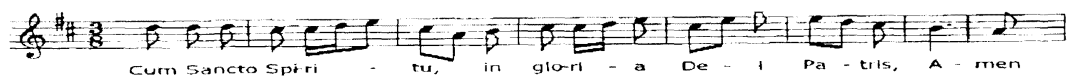

Moreover, in Praise the Lord we find specific textual references to the individual celebrating her birthday, Duchess Hedwig Friederike. The first recitative, for instance, an accompagnato, opens with 'Durchlauchtigste!' ('Gracious Duchess!') and addresses her as 'teuere Fürstin' ('cherished duchess'). The opening of the second recitative (movement 7) highlights the duchy of Anhalt-Zerbst ('Beglücktes Anhalt', 'Delighted Anhalt') before Fasch inserts a choral passage accompanied by oboes, strings and B. c. This deliberate musical interpretation of the text -

'Johann Friedrich Faschs ... Geburtstagskantaten' 205, n 44. See also Gregory Johnston, 'Self-Borrowing in Johann Friedrich Fasch's Cantatas: Die Starken bedürfen des Arztes nicht and Lobe den Herrn, meine Seele,' Johann Friedrich Fasch und sein Wirken für Zerbst: Report on the International Scholarly Conference on 18 and 19 April 1997 on the Occasion of the Fifth International Fasch Festival in Zerbst, ed. Konstanze Musketa and Barbara M. Reul (Dessau: Anhaltische Verlagsgesellschaft, 1997) 142-152. He points out that Fasch also employed this type of 'self-borrowing' in his regular Sunday and 'Aposteltage' cantatas. For an overview and examination of Fasch's masses, see Raymond Dittrich, Die Messen von Johann Friedrich Fasch (1688-1758), 2 vols. (Frankfurt am Main: P. Lang, 1992). 
Duchess Hedwig represents 'Die Freude unsers Theuresten August' ('The delight of our most cherished [Duke Johann] August') to all subjects, hence the tutti scoring - is followed by an accompagnato. Here two singers, instead of the conventional single vocalist in recitatives, extend their best wishes to the duchess ('Ihr sey von nichts, als lauter Wohl bewust', 'May she feel nothing but happiness'). Interestingly, from 1730/31 Fasch began to heavily favour recitatives accompanied by strings that involved at least two singers. ${ }^{33}$ Since all recitatives in the surviving cantatas of his $1735 / 36$ cycle are accompagnat $i$ in which the text is divided between two and four vocalists (SATB), ${ }^{34}$ this noticeable difference in scoring and texture provides an important clue with regard to the date of composition of sacred works by the Anhalt-Zerbst Kapellmeister that otherwise cannot be dated with certainty. ${ }^{35}$

For the two duet movements in Praise the Lord (see Overview 2 above) Fasch opted to employ a solo oboe both times, choosing the tenor and bass soloists for the first duet (movement 3 ) and the upper voices for the second duet (movement 6 ). Since no other keyboard music by Fasch has survived, the latter movement is the only known composition by the Anhalt-Zerbst Kapellmeister that features a separate part for the organ, more specifically the organ register 'Vox humana.' This register, which sounds like a reed-like instrument, was definitely part of the organ that Caspar Sperling from Quedlinburg had built for the Zerbst Court Chapel in $1712 .{ }^{36}$ When entering the organ part into the score Fasch seemed to have been unclear as to where he wanted to position the solo registerabove the vocal parts or above the continuo part? His indecisiveness possibly implies a second obbligato oboe part which eventually was replaced with the 'Vox humana' register. Fasch, an accomplished organ-

33 See also Gottfried Gille, Johann Friedrich Fasch (1688-1758): Kirchenkantaten in Jahrgängen: Ein Katalog der gedruckten Texte, ed. E. Thom, vol. 1 (Michaelstein: Kulturund Forschungsstätte Michaelstein, Institut für Aufführungspraxis, 1989) 34-35, 68-69, 85-86.

34 See Reul, 'The Sacred Cantatas of Johann Friedrich Fasch (1688-1758),' diss., U of Victoria, 1996, 277ff. and Reul, 'Musical-Liturgical Activities' 64. 'Das in Bitte, Gebeth, Fürbitte und Dancksagung bestehende Opffer' was Fasch's favourite cantata cycle: he performed it no fewer than seven times in 18 years.

35 See Engelke, Johann Friedrich Fasch: sein Leben und seine Tätigkeit als Vokalkomponist, diss. U of Leipzig, 1908 (Halle: C. A. Kaemmerer, 1908); the appendix includes a thematic catalogue. Cf. Pfeiffer, FWV, 32ff, Gille vols. 1 and 2, and Reul, 'Sacred Cantatas' $171 \mathrm{ff}$.

36 The disposition of the organ is reproduced in Wäschke, 'Die Schloßkapelle' 2. 
ist himself (he had worked in this capacity in a previous employment situation in Greiz in 1719), opted for the most practical solution. He wrote the 'Vox humana' part above the Basso continuo part and thus designated it to be performed by the organist, using his right hand. The organist, however, would usually provide chords with his right hand as part of the Basso continuo accompaniment. By asking the keyboardist to transfer the chords to the left hand and use his feet to play the bass line Fasch altered the solo-accompaniment texture significantly.

What could have motivated him to change the scoring in the first place? Perhaps the second oboist had been a junior player or replacement who had indicated to the Kapellmeister that he was unable to handle virtuosic passages. This particular scenario is supported by the comparatively easy second oboe part in the opening tutti movement and the fact that the player was only expected to double a simple vocal line in the closing chorale. A demanding organ part could also imply that Fasch had composed it especially to showcase the technical abilities of a visiting artist. However, Zerbst court records from 1725 do not mention a payment made to a guest organist on the occasion of the duchess's birthday. This leaves us with two possibilities. Either court organist Ulich, who had joined the court orchestra during the church year of $1723 / 24$, functioned as both an instrumental soloist and accompanist on 29 October $1725^{37}$ or Fasch himself had taken the opportunity to display his superior organ skills as a special sign of musical devotion to the duchess.

For many years the closing chorale of Praise the Lord has presented a problem for performers and editors (see Example 3). It contains clefs, accidentals, the metre of the chorale melody and its text but no musical setting. ${ }^{38}$ In addition, there is no reference to the respective column in the Zerbst hymnal which, in turn, would have enabled us to identify its

37 See Reul, 'Johann Friedrich Faschs ... Geburtstagskantaten' 206-207. Previously, only Fasch and a visiting guest organist had been considered as possible performers. Taking into account, however, that Ulich accompanied those services on the organ that were held at the court chapel on the days and did involve the choir and orchestra, he must surely have been able to handle difficult repertoire.

38 Reprinted by permission of the Hessische Landes- und Hochschulbibliothek Darmstadt. Incidentally, when this cantata was premiered in Darmstadt in 1983 as part of a music festival dedicated to Darmstadt's Kapellmeister Christoph Graupner, a festive chorale by Graupner was used. I would like to thank Dr. Oswald Bill, retired director of the Musikabteilung, Hessische Landes- und Hochschulbibliothek Darmstadt, for providing me with this information. 
Example 3: J. F. Fasch, Praise my Soul, FWV D: L2, movement 8, 'Gott, nimm das Opffer an', final chorale

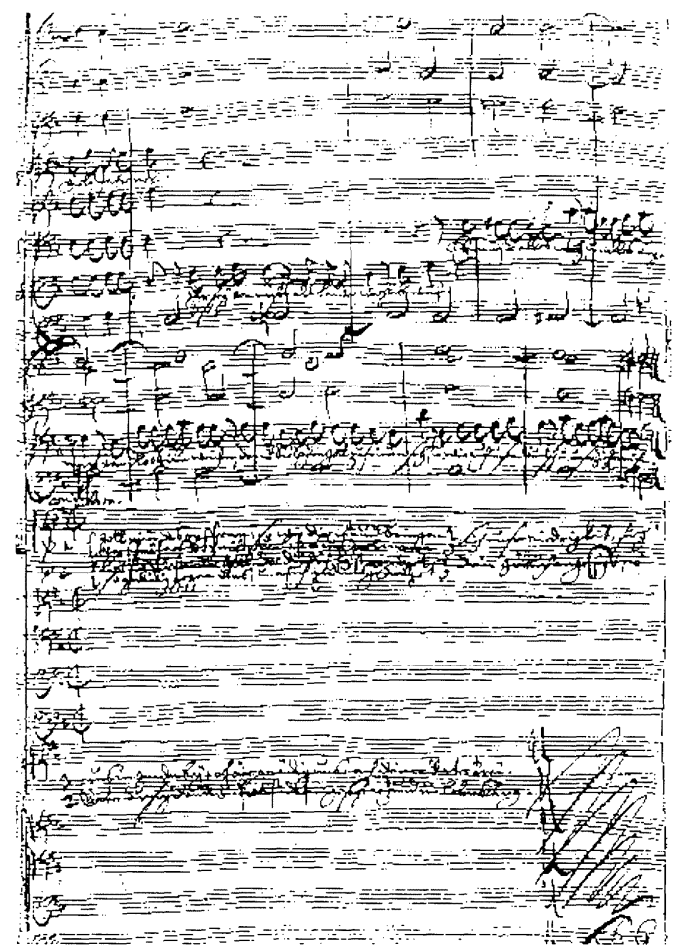

melody in the Zerbst Kantional (organist's edition) from $1738 .{ }^{39}$ Did the poet of the cantata libretto also author the final chorale? An examination of a Zerbst hymnal from 1743 that survives at the British Library, shows that the chorale text is identical with verses 5 und 6 of chorale no. 504 'Frohlocket, preiset Gott' ('Be joyful, praise God'). ${ }^{40}$ Printed in column

39 Cf. LHSA, Abt. Dessau, Zerbster Kantional from 1738. The other chorale is 'Gieb dich zufrieden, und sey stille', verses 1 and 2 of the hymn with the same title, see Zerbst Hymnal 1099, 15 verses; no. 399 in the 1738 Kantional. There is no reference to the Zerbst Hymnal in the libretto for this chorale either, possibly an oversight of the Hofdrucker Samuel Tietze.

40 I would like to express my sincere gratitude to Nigel Springthorpe, Welwyn, UK, who identified this chorale for me in the primary source at the British Library, GB-BL, Sign. 3425.K. 1. See Reul 'Johann Friedrich Faschs: Geburtstagskantaten', 208, n 52. The 
1373 , these verses were sung to the melody 'Nun danket alle Gott' ('Now thank we all our God') in Zerbst. Obviously, Fasch had been pressed for time when preparing the score and most likely had asked his copyist to use a setting of this well-known chorale melody from another cantata, to be entered into the (unfortunately missing) performance parts. ${ }^{41}$

In summary, congratulating one's 'noble and most gracious employer' on his or her birthday with premieres of festive sacred cantatas during worship services was customary at the Court of Anhalt-Zerbst throughout the first half of the eighteenth century. Johann Friedrich Fasch contributed numerous compositions to this fascinating musical genre, but only two occasional works for Duchess Hedwig Friederike of Anhalt-Zerbst survive in Darmstadt, Die Gerechten müssen sich freuen (1722) and Praise the Lord O my soul (1725). An examination of the latter work within its performance-practical context at the Court Chapel has shown that Duchess Hedwig Friederike, to whom the work was dedicated, enjoyed a special musical-liturgical status on her anniversary. The order of her birthday service was clearly modelled after those celebrated on minor feast days at the chapel, thus elevating the duchess to the rank of a saint. Additional signs of devotion on the part of the poet who was 'speaking' on behalf of the entire principality, include addressing her, her subjects and her husband, the duke, specifically in the recitatives. On a purely musical level we note Fasch's special interest in varying the texture and scoring of each movement to hold the attention of his honourable listener. Moreover, Fasch went beyond the conventional number of vocalists in his accompanied recitatives and employed an obbligato organ register instead of another oboe in the second duet movement. Neglecting to write out the final chorale illustrates Fasch's

London copy of the Zerbst Hymnal from 1743 contains twelve additional chorales with the metre 67676666 . Chorales nos. 179, 180, and 504 were also sung to the melody 'Now thank we all our God.' The melody 'God, you pious God' ('Oh Gott, du frommer Gott') was employed for the chorales nos. 120, 239, 377, 386, 453, 454, 465, 480 and 496.

41 Reul, 'Johann Friedrich Faschs ... Geburtstagskantaten' 208, n 53. Johann Sebastian Bach and his son Wilhelm Friedemann Bach must have found themselves in similar situations because they, too, did not finish writing out final chorales. Cf. BWV 59 (final chorale missing) and BWV 163 (Bach only provided the continuo part, noting 'in simplice stylo'); see also the following cantatas by Wilhelm Friedemann Bach in Martin Falck, Wilhelm Friedemann Bach: sein Leben und seine Werke mit thematischem Verzeichnis und zwei Bildern (Leipzig, 1913): Fk 74 (final chorale is missing), Fk 86 (only the first measure was written out) and Fk 96 (chorale text is missing). I would like to thank Peter Wollny, Bach-Archiv Leipzig, for providing me with this information. 
way of coping with his intense workload as Kapellmeister of this small, yet musically very active court in Central Germany.

It is my hope that specialized research with regard to the structural design of surviving libretti to Fasch's birthday cantatas will provide us with much needed clues as to how these works would have sounded. This, in turn, will enable us to compare them to compositions for similar occasions contributed by Fasch's contemporaries, in particular to birthday cantatas penned by J. S. Bach, Kantor in Leipzig, and G. P. Telemann, civic musical director in Hamburg.

BARBARA M. REUL

Luther College, University of Regina 